\title{
On the Intersectionality of Transnationalism and Citizenship
}

\author{
Lori Wilkinson (University of Manitoba)
}

\begin{abstract}
Seen positively, transnationalism enriches the cultural, linguistic and religious diversity of many countries and enhances the exchange of goods and services in the increasingly globalized economy. Seen negatively, transnationalism creates disunity in terms of introducing new ethnic, linguistic and religious traditions in developed countries, and poses risks to security and national well being. This paper examines citizenship conceptions, policies and practices directed towards transnational migrants within the European Union, the United States, and Canada.
\end{abstract}

Résumé : D’un point de vue positif, le transnationalisme enrichit la diversité culturelle, linguistique et religieuse de plusieurs pays et il accroît les échanges de produits et services dans une économie de plus en plus mondialisée. D'un point de vue négatif, le transnationalisme crée des pertes d'unité par l'introduction de nouvelles traditions ethniques, linguistiques et religieuses dans les pays développés, de même qu'il pose des risques à la sécurité et au bien-être national. Cet article examine les conceptions de la citoyenneté, les politiques et les pratiques à l'égard des migrants transnationaux dans l’Union européenne, aux États-Unis et au Canada.

\section{Competing Forms of Citizenship}

Based on the common idea that well-being and freedom are granted by the state in exchange for citizens' allegiance and obedience, citizenship forms the basis of responsibility and belonging for all individuals (Isin and Turner, 2002). Seen this way, citizenship requires nationalism among loyal citizens through connections to a common ethnicity, history, language, religion, and culture (Brubaker, 2003). Yet this view of citizenship as a legal concept of belonging is increasingly criticized because it assumes that citizens must have ties to only one single culture, language, history or religion, and to the nation-state, perceived as antiquated.

Post-national interpretations of citizenship argue that given the demise of the nation-state, there is no longer a need to embed notions of belonging within the framework of common culture, language and history (Klusmeyer, 2001). Others argue, however, that citizenship goes beyond membership within a nation and that it has more holistic meanings, making room for multiple forms of membership and affiliation (Bosniak, 2001). This conceptual and policy issue becomes more acute with increasing exchanges of economic goods, with advances in technology for communication and transportation, and with the maintenance of international social networks. Given the impact of

68 Canadian and International Education Vol. 34 no. 1 - June 2005 
transnationalism and integration on contemporary and new understandings of citizenship, three questions form the nexus of this study: ${ }^{1}$ (1) How is citizenship understood in a world of transnationalism, migration and diverse values? (2) What can practices from other countries tell us about the development of citizenship today? (3) How do policies and practices give rise to contradictory measures which guarantee freedom of expression while excluding the expression of this democratic ideal in public institutions?

\section{Transnationalism: Definitions, Characteristics and Consequences}

In order to understand transculturalism fully, there is a clear need to examine both the integration of immigrants in their new society and their continuing engagement with home countries. Transnationalism and immigrant integration are often treated separately although they are closely related processes. Moreover, there are two concurrent but potentially contradictory perspectives which, in my understanding, may be unduly alarming governments, politicians, and academics.

What is transnationalism? A dynamic process whereby immigrants maintain and encourage linkages between former and new countries, transnationalism refers to a combination of varying, and at times contradictory identities including "civic-political memberships, economic involvements, social networks and cultural identities that links people and institutions in two or more nation-states in diverse, multilayered patterns" (Morawska, 2003: 175-176). In other words, immigrants are not only nationals of one particular country of residence, but they are active members of an interconnected international community (Glick et al, 1999). Their importance is revealed in their opening up otherwise closed economic markets by creating new international ties between the sending and receiving countries, helping to create global economies and labour markets.

Transnationalism is not a new phenomenon, as circular, return and multiple migrations are not much different to previous periods of migration. Immigrants kept in contact with their homeland through letters, gifts, goods, services and even brides throughout the eighteenth, nineteenth and twentieth centuries (Morawska, 2003). A distinction may be made however, for diasporic communities are "migrant communities that are permanently settled abroad and that maintain an identity based on cultural origins of their country of origin" (Voigt-Graf, 2003: 368) for whom return to a homeland is impossible. In contrast, the transnational communities have continuous and real personal and

\footnotetext{
${ }^{1}$ Research funding is gratefully acknowledged from the Prairie Centre of Excellence for Research on Immigration and Integration, the Social Sciences and Humanities Research Council and the Policy Research Initiative Project on Trends, for the project, Citizenship Values: State of the Art Review, with Yvonne Hébert as principal researcher and Lori Wilkinson as co-researcher.
} 
material links, although both types of community can characteristically share memories, religious and cultural practices.

The consequences of transnationalism play out unevenly among various migrant groups in many countries, influencing their integration into society, and causing problems of disunity, social instability and exclusion (Morawska, 2003; Glick et al, 1999). For example, for Indo-Americans, transnationalism involves sending remittances to family members outside the country. For other DominicanAmericans, transnationalism also includes investment in small businesses, frequent visits and the acceptance of dual citizenship. Indo-Americans have successfully integrated economically and socially, having high rates of postsecondary education and relatively good professional and occupational attainments. By comparison, Dominican-Americans have not fared as well for their heavy transnational involvement is perceived as having slowed their integration, and are alleged to contribute to their lower levels of educational attainment and low rates of English language acquisition (Morawska, 2003), although participation in the wider pan-Hispanic alliance has helped their integration to a certain extent.

Transnational communities may face isolation because they may lack sufficient ties with both their home country as well as their new host country of residence. In other words, members are not integral to either their home societies or the host society due to cultural, linguistic, religious, or other differences. Because of their role as two-way transmitters of culture, religion and trade, these individuals lack dense social and cultural ties to places of origin, may be reluctant to integrate into new societies, become disengaged and increasingly isolated from both societies, possibly leading to social exclusion (Vertovec \& Cohen, 1999). According to this view, migrants are defined as a threat to social cohesion, to national security, and to the destruction of the nation-state, particularly in an era of increasing terrorism and interethnic violence, thus interfering with the stability of the nation-state and challenging the conceptualization of citizenship (Joppke \& Morawska, 2003).

\section{Migration and Obligations of the State: Dual Citizenship}

There is a need and obligation on the part of the state to ensure that all immigrant groups are integrated successfully into society. Canada has been relatively successful given the increasing rates of educational achievement, occupational attainment, and increasing participation of immigrants in all levels of politics, in terms of increased voting and increased representation. However, there is still cause for concern, given that some immigrant groups are having difficulties adjusting to their new lives as evidenced by their overall low level of integration, low levels of education, and low proficiency in either of the two official languages. Some immigrants respond with a strong desire for duality. From an ideological standpoint, dual citizenship very much supports the ideals 
of most liberal democratic countries in the freedom to celebrate diversity in terms of religion, culture, language, and other lifestyles without fear of persecution.

Dual citizenship positively induces migrants to introduce new business and maintain social ties between their former and current countries of residence, feeding into one of the overarching premises of globalization - that of increased trade of capital, resources and people. This is not a problem in Canada, Mexico, Turkey, and other countries that already recognize dual passports and citizenships. For other countries, however, it is a deeply divisive issue. The European Union is experiencing disagreements among its constituent members regarding the recognition of dual passports and citizenships. Countries like Austria and Denmark reject the idea of dual citizenships, while France and the UK are somewhat more tolerant.

Governments may be suspicious of the intentions of dual citizenship holders, questioning loyalty and commitment. Even where dual citizenships are recognized, there are no guarantees that an individual's rights are protected, as illustrated briefly in two examples. First, in Canada, this is illustrated in the recent case of dual Syrian/Canadian citizen Maher Arar, the Ottawa-area resident deported to Syria upon arrival to the United States, despite the fact that he was carrying a Canadian passport and that the Americans knew that the Syrian government openly uses torture on terrorist suspects (CBC News OnLine, 2004). Second, the erosion of individual rights in the United States and elsewhere typifies the post-September 11 era. The discrimination faced by Muslims and Jews after the terrorist attacks are primary examples of the perceived threat of others to American security.

\section{Transnationalism and International Citizenship Policies: Three Cases Examined}

\section{Conceptualizing Supra-National Citizenship: The Case of the European Union}

The European Union model of citizenship represents a dramatic shift towards a new form of postnational citizenship (Martiniello, 2000) yet much may be learned from the EU debates on citizenship policies. In this international union, citizenship can no longer be defined as having a fixed national border containing peoples of similar histories, language and culture. In the Maastricht Treaty of 1993, amended by the Amsterdam Treaty of 1995, citizenship in the EU is defined in objective terms as:

the rights of freedom of movement and residence on the territory of the member states, the right to vote and to be elected in the local elections and in the elections of the European Parliament in the member state of residence, the right to diplomatic protection in a third country, and the 
right to petition the European Parliament as well as the possibility to appeal to a European ombudsman (Martiniello, 2000: 347)

One of its major challenges is to maintain a cohesive identity in the face of multiple cultures, languages, religions and geographical distances (Wihtol, 2002). Each member state has very different ideas, definitions and legal processes for obtaining citizenship. Until recently, Germany's citizenship legislation made it very difficult for immigrants and children of immigrants to obtain citizenship only open to those who could prove direct German family lineages. This left many individuals, including Turkish workers, unable to obtain citizenship despite having lived there for three or more generations. By comparison, Algerians living in France were naturalized, without being accepted as 'real' French, in light of their colonial legacy (Joppke \& Morawska, 2003; see also Mbele, pp. 78-89). This is further compounded by other forms of quasicitizenship practiced in all EU countries. Each member state has different rules regarding the rights and obligations of resident non-citizens. Landed migrants have the right to vote in national elections in Sweden, Denmark, the Netherlands and Norway, but lack this opportunity elsewhere (Wihtol, 2002).

Other differences demarcate the evolution of identity and belonging in the EU. In some countries, like the United Kingdom and Norway, the government is heavily involved in resettlement and integration, via designated nongovernmental agencies that aid in the settlement of newcomers. In other countries, such as Italy, immigrants are on their own to find education, housing and employment. The result is uneven practices and variability in integration outcomes. Already, several EU member-states have received complaints of human rights violations, mainly due to problems in recognizing the right of expression of cultural, religious, or linguistic identities. If legislation within the Union was documented so that member-states could refer to a concise document, it would provide guidance and consistency to the application of citizenship across the EU and may lead to the recognition of subjective forms within new understandings of citizenship (Leveau et al, 2002).

The degree to which integration is successful depends upon the context of arrival (host country receptivity) and the nature of the individual (receptivity to integration). In addition to differences between member-states, a macro-EU citizenship must deal with their replication on a national level within individual countries, as well as the integration of the ethnic and religious differences of immigrants. With the entry of ten new, mainly former Soviet bloc countries in May 2004, this is of great concern to countries such as Germany, France and the UK, who fear that migrants will flock over as the restrictions to migration decrease. From my perspective, discussions of EU citizenship need to consider these realities and the different value systems of migrants when designing new citizenship models. 


\section{Citizenship in an Era of Insecurity: The Case of the United States}

Migration and transnationalism is seen as both a benefit to American society and the development of its national identity, as well as a serious detriment to the national security and unity. In terms of its benefits, the immigrant plays an important role in myths of nation-building. The mythical construction of America is based on stories of hardworking newcomers who tamed the prairies, mountains and coastal regions, making way for the arrival of their kinsmen and the chance to practice their religion and other beliefs free from oppression. Migrants provide native-born Americans with strong affirmation of the greatness of their country given all the obstacles that most immigrants must overcome to arrive in the US and obtain the American dream of life, liberty and happiness (Honig, 2001). The many positive myths associated with migration in America include hard work as the means to success and strong family values which will reinvigorate an increasingly morally corrupt American population. Additionally, given the immigrant drive and determination to succeed, they are likely to participate in society by voting and engaging in other initiatives, more so than the native-born American (Honig, 2001).

Increasingly, however, negative images of the immigrant give rise to five myths. The first one dwells on the necessity for the management of cultural diversity. If there are too many cultures, the Anglo-American culture as base culture is in threat of extinction and the stability of society is in jeopardy, for example, from the burgeoning Hispanic population which is expected to represent one quarter of the population by 2050, surpassing African-Americans (Bader, 1997). This fear feeds increased calls for the preservation of the English language and for the encouragement of American culture in schools. The second myth concerns the common belief that immigrants take jobs away from native-born workers and thus contributing to high rates of unemployment. Although this argument has no merit, the belief persists in the minds of the public.

A third myth equates migration with crime and terrorist activity. There are calls throughout the developed world, including the United States, to tighten migration laws in fear of allowing criminals an easy access to an increasingly vulnerable public. Media reports hype the idea that migration controls are easily permeated by criminal elements. This argument has dubious merit for the last thing any potential criminal or terrorist would want is the added attention and scrutiny of background, medical and security/criminal checks that come with application for landed immigrant or refugee asylum. Common sense would dictate that potential criminals use other means to enter the country, beneath the radar of the receiving governments.

The fourth negative myth concerns illegal migration. In addition to the element of fear in a post 9-11 context, illegal immigrants are depicted by the media and by government officials as arriving in metaphoric waves, drones, or floods, 
taking advantage of the kindness of receiving states and their generous social welfare policies (Honig, 2001).

Finally, a fifth myth feeds a concern that immigrants may not invest into their receiving society, preferring instead to send their earnings home to families abroad in the form of remittances, bleeding the American economy and possibly breeding another concern, that of the funding of terrorist activities. While these sentiments are present in other countries, the presence of these myths as negative value systems is very strong in the United States.

\section{Citizenship and Multiple Identities: The Case of Canada}

A multinational state, Canada uniquely expresses its citizenship through its commitment to multiculturalism. While this may have positive benefits in terms of the willingness to accept difference at least superficially, there remains an indeterminacy or fluidity regarding the exact nature of Canadian citizenship and culture. This country also demonstrates many of the positive and negative views of immigrants, values and citizenship discussed in previous sections. However, one of the major differences is that multiculturalism in Canada is inscribed in law, whereas in the United States it is neither official policy nor legislation (Joppke \& Morawska, 2003). While this provides newcomers to Canada a better guarantee of the right to live their culture, language and religion, this also feeds concerns regarding long-term insecurity and social cohesion.

Multiculturalism itself is seen both positively and negatively. Ideally, "to be a Canadian, it was hoped, could be compatible with other ethnic type identities it encompassed" (Juteau, 1997: 105). In other words, Canadian identity is intended as a hybridization of affiliations to the country and to ethnic and religious groups, the combination of which depends on the individual. Nevertheless, multiculturalism is seen by some as a threat to citizenship, to a sense of social cohesion and political unity because of its celebration of diversity and values which can be detrimental to national unity and contradictory loyalties.

Canada shows signs of increasing boundaries and decreasing access to citizenship in an increasingly insecure world. Strengthening political unity, encouraging social cohesion, and the belief that immigrants pose a threat to society, are reasons behind the tightening of citizenship regulations. A separatist province "aspires to develop its own concept of citizenship based on a distinct vision of the Québec political community" (Labelle \& Salée, 2001: 279). While Québécois are readily able to define themselves as a people, amongst immigrants and other minority groups in Québec, there remains some opposition to the Québecois discourse which takes up all the place of nationalism, along with a sense of not truly belonging, in spite of assurances that the state wishes to interact "with them, within a common civic framework, applicable to all without distinction" (Labelle \& Salée, 2001: 289). This is very similar to the vision of 
citizenship of the Canadian federal government, with loyalty to Canada first and foremost, and other loyalties as secondary.

\section{Conclusion}

Despite the development of macro-units such as the European Union and the North Atlantic Free Trade Agreement, citizenship as a model for belonging seems to persist at the level of the plural state. The nature and practice of citizenship, however, are expanding so as to consider subjective aspects, not the least of which are the rights of belonging and expression. Governments and host societies must find more pro-active ways of inviting newcomers to participate as equals in their new adoptive homes so as to lessen prospective troubles with exclusion, isolation and social cohesion in the near future. Given the issue of allegiance of immigrants, a balanced demonstration of the benefits of transnationalism is needed, one that encourages the sharing of culture, values, religion, social and economic capital without lessening societal and political strengths of receiving countries.

Transnationalism is intimately tied to migration and integration (Voigt-Graf, 2003); however, many issues surrounding transnationalism and citizenship that have been identified: loyal allegiance, dual citizenship, engagement, and participation in the host country. The most troubling aspect of new forms of citizenship and belonging, however, is the evidence that suggests that some transnational communities are isolated and excluded by the host society, fitting in with neither their country of origin nor in the host society.

The common feature of all countries examined is the increasing need for cheap labour, mostly foreign, brought into a host society at the bottom of the social ladder. The European Union faces problems of harmonizing citizenship practices while working on integrative policies. Juggling of ethnic, religious, cultural and linguistic differences requires much more than new citizenship policies and security measures; it will take concerted effort on several fronts to engage and celebrate diversity with authenticity, equality and respect. In the United States, transnationalism is at the nexus of national myths and security threats. The positive effects brought by immigrants are increasingly integral to the workings of the American economy which is highly dependent on international exchange of investment, goods and services; however, the postSeptember 11 questioning of foreigners creates a two-tiered system of citizenship of inclusion and exclusion. Finally, Canada evidences many of the same threats to citizenship as identified in the United States. There is however little to worry about in terms of the loyalty of newcomers who indicate a desire to remain connected with their homelands (Labelle and Salée (2001). Maintaining these ties as memories makes it difficult to simply leave any homeland behind, forgotten and abandoned. Today, this is neither necessary, nor wise. 


\section{References}

Bader, V. (1997). Fairly open borders. In V. Bader (Ed.), Citizenship and exclusion (pp. 28-60). New York: St. Martin's Press.

Bosniak, L. (2001). Denationalizing citizenship. In T. A. Aleinikoff \& D. Klusmeyer (Eds.), Citizenship today: Global perspectives and practices (pp. 237-252). Washington, DC: Carnegie Endowment for International Peace.

Brubaker, R. (2003). The return of assimilation? Changing perspectives on immigration and its sequels in France, Germany and the United States. In C. Joppke \& E. Morawska (Eds.), Toward assimilation and citizenship: Immigrants in liberal nation-states (pp. 39-58). Basingstoke, UK: Palgrave Macmillan, pp. 39-58.

CBC News (2004). CBC news in-depth: Maher Arar Timeline www.cbc.ca/news/background/arar/ Accessed 01 April 2004.

Glick, N. S., Basch L., \& Blanc-Szanton, C. (1999). Transnationalism: A new analytic framework for understanding migration. In S. Vertovec \& R. Cohen (Eds.), Migration, diasporas and transnationalism (pp. 26-49). Cheltenham, UK: Edward Elgar.

Honig, B. (2001). Democracy and the foreigner. Princeton and Oxford: Princeton University Press.

Isin, E. F. \& Turner B. S. (2002). Handbook of citizenship studies. Thousand Oaks, CA: Sage.

Joppke, C. \& Morawska, E. (2003). Integrating immigrants in liberal nation-states: Policies and practices. In C. Joppke \& E. Morawska (Eds.), Toward assimilation and citizenship: Immigrants in liberal nation-state (pp. 1-36). Basingstoke, UK: Palgrave Macmillan.

Juteau, D. (1997). Multicultural citizenship: The challenge of pluralism in Canada. In V. Bader (Ed.), Citizenship and exclusion (pp. 96-112). Basingstoke, UK: Macmillan.

Klusmeyer, D. (2001). Introduction. In T. A. Aleinikoff \& D. Klusmeyer (Eds.), Citizenship today: Global perspectives and practices (pp. 1-16). Washington, DC: Carnegie Endowment for Peace.

Labelle, M. \& Salée, D. (2001). Immigrant and minority representations of citizenship in Quebec. In T. A. Aleinikoff \& D. Klusmeyer (Eds.), Citizenship today: Global perspectives and practices (pp. 278-315). Washington, DC: Carnegie Endowment for Peace.

Leveau, R., Mohsen-Finan, K. \& Wihtol de Wenden, C. (2002). Introduction. In R. Leveau, K. Mohsen-Finan \& C. Wihtol de Wenden (Eds.), New European identity and citizenship (pp. ix-xv). Aldershot, UK: Ashgate.

Martiniello, M. (2000). Citizenship in the European Union. In T. A. Aleinikoff \& D. Klusmeyer (Eds.), From migrants to citizens: Membership in a changing world (pp. 342-380). Washington, DC: Carnegie Endowment for Peace.

Morawska, E. (2003). Immigrant transnationalism and assimilation: A variety of combinations and the analytic strategy it suggests. In C. Joppke \& E. Morawska (Eds.), Toward assimilation and citizenship: Immigrants in liberal nation-states (pp. 133-176). Basingstoke, UK: Palgrave Macmillan.

Vertovec, S. \& Cohen, R. (Eds.). (1999). Migration, diasporas and transnationalism. Cheltenham, UK: Edward Elgar.

Voigt-Graf, C. (2003). The emergence of an Indo-Fijian transnational community. In R. Iredale, C. Hawksley \& S. Castles (Eds.), Migration in the Asia Pacific:

76 Canadian and International Education Vol. 34 no. 1 - June 2005 
Population, settlement and citizenship issues (pp.367-387). Cheltenham, UK: Edward Elgar.

Wihtol de Wenden, C. (2002). European citizenship and migration. In R. Leveau, K. Mohsen-Finan \& C. Wihtol de Wenden (Eds.), New European identity and citizenship (pp.79-89). Aldershot, UK: Ashgate. 